\title{
ПІДВИЩЕННЯ ЯКОСТІ УПРАВЛІННЯ ПЕРСОНАЛОМ В СУЧАСНИХ УМОВАХ
}

\section{IMPROVING THE QUALITY OF PERSONELL MANAGEMENT IN MODERN CONDITIONS}

\author{
Сорока Олександра Володимирівна \\ кандидат економічних наук, доцент, \\ Одеський національний економічний університет \\ ORCID: https://orcid.org/0000-0001-6982-1817 \\ Унгурян Анастасія Сергіївна \\ магістр, \\ Одеський національний економічний університет \\ ORCID: https://orcid.org/0000-0001-5700-3171 \\ Арутюнян Асмік Седраківна \\ магістр, \\ Одеський національний економічний університет \\ ORCID: https://orcid.org/0000-0001-9328-4660
}

\author{
Soroka Olekandra, Unhurian Anastasiia, Arytiunian Asmik \\ Odessa National Economic University
}

\begin{abstract}
У статті розглядається вплив різноманітних фракторів на якість управління персоналом. Проаналізовано і систематизовано фактори, які впливають на якість управління розвитком персоналу. Визначено фрункції управління компетенціями на рівні підприємства. Враховуючи той фракт, що одна із функцій мотивації полягає у визначенні потреб персоналу та забезпеченні їх задоволення в організації визначено зв'язок між мотивацією персоналу та розвитком компетенцій. Систематизовано та проаналізовано різні точки зору щодо корпоративної культури на підприємстві і її впливу на якість управління персоналом. Враховуючи результати дослідження зроблено висновки, що на якість управління персоналом досліджені фактори впливають у рівній мірі. Запропоновано перш за все на вітчизняних підприємствах звернути увагу на нематеріальну складову мотивації персоналу та розробити більш комплексний підхід до управління персоналом.

Ключові слова: управління персоналом, мотивація, корпоративна культура, персонал, компетенція, розвиток персоналу.
\end{abstract}

В статье рассматривается влияние различных фракторов на качество управления персоналом. Проанализированы и систематизированы факторы, влияющие на качество управления развитием персонала. Определены функции управления компетенциями на уровне предприятия. Учитывая тот фракт, что одна из фрункций мотивации заключается в определении потребностей персонала и обеспечении их удовлетворения в организации определена связь между мотивацией персонала и развитием компетенций. Систематизированы и проанализированы различные точки зрения относительно корпоративной культуры на предприятии и ее влияния на качество управления персоналом. Учитывая результаты исследования сделаны выводы, что на качество управления персоналом рассмотренные фракторы влияют в равной степени. Предложено прежде всего на отечественных предприятиях обратить внимание на нематериальную составляющую мотивации персонала и разработать более комплексный подход к управлению персоналом.

Ключевые слова: управление персоналом, мотиваия, корпоративная культура, персонал, компетенция, развитие персонала.

The article highlights the problem of the quality of personnel management at domestic enterprises. Since during the period of constant economic changes in our country there are a number of problems in determining a unified approach to personnel management, it is necessary to highlight the factors that have the biggest impact on the quality of personnel management. The article analyzes and systematizes the factors influencing the quality of personnel development management. The functions of competence management at the enterprise level are determined. Giving the 
fact that the main functions of motivation are to determine the needs of personnel and ensure their satisfaction in the organization, the development of systems of remuneration for the work performed and the use of incentives for effective interaction of employees in teams and at the enterprise as a whole, the relationship between personnel motivation and the development of competencies has been determined. It was also determined that the factors for increasing the efficiency of labor motivation that was described in the article will work if the team in the company is integral and cohesive. Based on this, conclusions were drawn about the relationship between labor motivation and corporate culture. The modern problems of the formation of corporate culture are identified, various points of view regarding the corporate culture at the enterprise and its influence on the quality of personnel management are systematized and analyzed. Taking into account the results of the study, it was concluded that the actors have an equal impact on the quality of personnel management, since personnel management concerns directly the personnel who are involved in all areas of the enterprise and the results of the company's work depend on the personnel. It is proposed, first of all, at domestic enterprises to pay attention to the intangible component of personnel motivation, since at present at most enterprises only material labor motivation is used, and to develop a more comprehensive approach to personnel management to improve the efficiency of the entire enterprise. On the prospects for further developments, it was concluded that now it is necessary to develop a personnel management system that will be based on the principles of humanism and consider the employee not as a resource for increasing profits, but primarily as a person.

Keywords: personnel management, motivation, corporate culture, personnel, competence, personnel development.

Постановка проблеми. Серед великої кількості соціально-економічних завдань, які виникають в нашій країні в сучасних реаліях, основною проблемою $є$ проблема низької якості робіт та послуг. Багато сучасних українських менеджерів не розуміють, що без дотримання певних стандартів їх організаціям буде важко просунути будь-яку продукцію на ринок, на міжнародну арену, а вже тим більше завоювати сегмент ринку. У попередні роки проблема якості розглядалась, як технічна проблема, пов'язана, в першу чергу, з недосконалістю техніки, а потім вже з якістю управління.

Світовий досвід показує, методи управління, які використовувалися раніше - вже застаріли, і з кожним роком, вони модернізуються і набирають більшої актуальності.

Однією 3 найголовніших соціальних перешкод впровадження еорективних зарубіжних концепцій управління якістю в Україні $€$ недостатня увага до людських ресурсів.

Резюмуючи вищевикладене, можна відзначити, що у період економічних змін в нашій країні необхідно виділити фрактори, які здійснюють найбільший вплив на якість управління персоналом.

Аналіз останніх досліджень і публікацій. Проблему підвищення якості управління персоналом було проаналізовано у статтях як вітчизняних так і зарубіжних вчених, таких як С.Н. Большаков, А.В. Костюков, А.Г. Журавльов, Ю.Г. Одегов, Б.Е. Татул, Н.Г. Рак, Г. Деслер, Т. Дейл, Б. Карлоф, К. Камерон та інших. На жаль у роботах авторів немає однозначного аналізу факторів,які впливають на якість управління персоналом. Саме тому ми спробуємо проаналізувати дану проблему з різних точок зору і виділити фактори, які мають найбільший вплив на якість управління персоналом.
Мета статті. Головною метою даної статті $\epsilon$ аналіз фракторів, які мають змогу підвищити якість управління персоналом в сучасних умовах.

Виклад основного матеріалу. У сучасних умовах одним 3 найважливіших умов фрункціонування та інноваційного розвитку підприємства $€$ ефрективна система управлінської діяльності.

Визначення показників оцінки якості управління персоналом організації на наш погляд $€$ одним 3 важливих методологічних засобів, що впливають на ефективність управління персоналом в цілому.

При оцінці ефективності управління персоналом підприємства необхідно акцентувати увагу на наступних важливих критеріях:

- уточнення цілей і завдань досліджуваної області;

- визначення сукупності заходів і засобів, необхідних для їх досягнення;

- встановлення реальних термінів досягнення намічених цілей і завдань, виходячи 3 наявних коштів і можливостей;

- знаходження коштів і методів для дієвого контролю за термінами реалізації намічених цілей і завдань на всіх рівнях;

- адекватне формування цілей і принципів кадрової політики, відповідної цілям, принципам і завдання стратегії організації [1].

Для системного аналізу впливу чинників на управління розвитком персоналу фрактори необхідно привести в систему, що дає можливість упорядкувати, детально вивчити кожну з груп і в результаті управляти впливом на процес управління розвитком людських ресурсів організації.

Також, можемо звернутися до фракторів, які, на нашу думку, позитивно впливають на якість управління персоналом. 
Класифрікація фракторів, що впливають на ефективність управління розвитком персоналу, за змістом, ґрунтується на виділенні чотирьох груп (рис. 1).

Запропонована класифрікація фракторів базується на положеннях теорії систем, бо, розглядаючи управління розвитком людськими ресурсами персоналу як процес, що має відповідні цілі розвитку, механізм управлінського інформаційно-енергетичного впливу, що виробляється засобами розвитку, і організацію праці, що надає організованість всіх елементів системи людської діяльності, можна констатувати , що властивості системи управління розвитком людськими ресурсами персоналу похідні від властивостей їі елементів. Зі зміною елементів системи змінюються і її властивості, а в результаті взаємодії елементів у системи управління розвитком з'являються нові властивості, відсутні у її елементів. Більш того, в запропонованій класифрікації поряд 3 системним підходом реалізований і комплексний, так як класифрікація представлена сукупністю психофрізіологічних, соціальних, організаційних, технологічних та інших фракторів, які в системі охоплюють всі аспекти управління і самоврядування розвитком.

Перш за все, хотілось відмітити, що важливою метою в управлінні $\epsilon$ компетенція.

Управління компетенцією персоналу являє собою процес порівняння потреб підприємства 3 наявними ресурсами і вибір форм впливу для приведення їх у відповідності на практиці. В даному випадку під ресурсами мається на увазі персонал підприємства 3 досягнутими рівнями компетенції, бажаннями, мотиваціями, устремліннями. Управління компетенцій може здійснюватися як на рівні підприємства, так і на рівні окремого працівника.
На рівні підприємства управління компетенцією пов'язане з наступними функціями:

- оцінка наявних ресурсів персоналу, а також можливостей, знань, навичок персоналу;

- оцінка потреб підприємства в персоналі відповідно до цілями, завданнями організації, встановленої підприємством стратегій на найближчі роки;

- оцінка на основі системного аналізу зіставлення ресурсів-потреб.

Далі, щоб виявити наскільки ці компетенції будуть проявлятися в колективі, на нашу думку, іншою важливою умовою підвищення есрективності управління персоналом $€$ мотивація трудової діяльності. Адміністратори завжди здійснювали умови мотивації своїх працівників, усвідомлюючи це чи ні. У давні часи, для цього служили батіг і загрози, для нечисленних обраних - нагороди.

Зміст фрункції мотивації полягає у визначенні потреб персоналу та забезпеченні їх задоволення в організації; розробленні систем винагороди за роботу, що виконується; застосуванні різноманітних фрорм оплати праці; використання стимулів ефективної взаємодії працівників у колективах і на підприємстві загалом. На рисунку 2 показано завдання, які вирішуються за допомогою мотивації.

Для підвищення есрективності управління персоналом необхідне вдосконалення мотивації працівників, що може дати:

- підвищення результативності роботи персоналу;

- оперативне досягнення цілей підприємства;

- зв'язок результативності роботи співробітників з оплатою та нематеріальним стимулюванням;

- прозорість системи заохочення;

- зниження плинності кадрів;

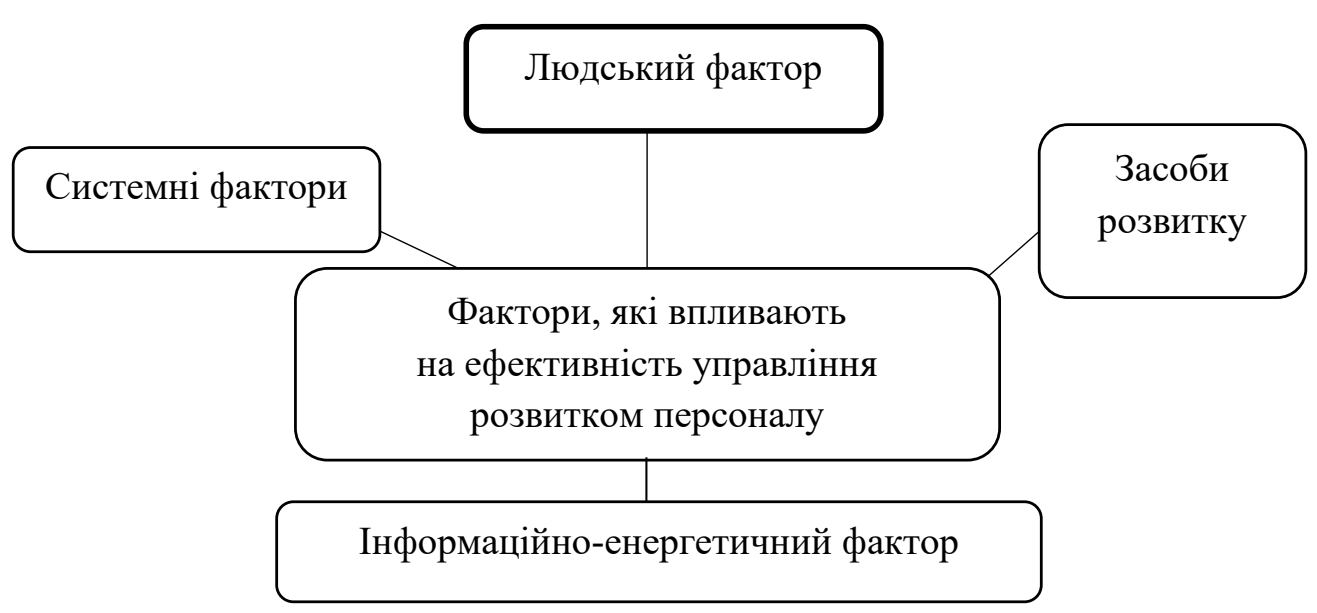

Рис. 1. Система факторів, що впливають на ефективність управління розвитком персоналу організації 


Завдання мотивації

Рис. 2. Завдання, які вирішує використання мотивації

- покращення психологічного клімату;

- покращення командної роботи [3].

Усі ці фрактори будуть ефективно працювати, якщо колектив в компанії будт згуртованим, цілісним та дружнім. Отже, наступним фрактором якісного управління персоналом - $€$ корпоративна культура. Аналіз останніх досліджень корпоративної культури привертає все більшу увагу науковців, проте, як в теоретичних, так і в практичних підходах можна виявити певні обмеження.

Сьогодні проблеми фрормування корпоративної культури часто зводяться до впровадження іміджевих та розважальних програм, тоді як її потенціал може бути розкритий лише за умови її значення у зростанні конкурентних переваг підприємства. Підхід українських вчених відносно рівня (якості) корпоративної культури базується переважно на моделях країн 3 розвиненим ринком та має яскраво виражений інноваційний аспект. Наведемо точки зору вчених на сутність та значення корпоративної культури у функціонуванні організації у таблиці 1.

Досліджуючи наведені в статті точки зору багатьох вчених, ми прийшли до висновку,що управління персоналом в цілому може мати дві складові: економічну і соціальну. Якщо на підприємстві більшу увагу звертають на еко- номічний аспект, то управління персоналом полягає в тому, щоб завдяки різним методам впливу на персонал та продуктивність праці персоналу, підвищити прибуток підприємства. Якщо розглядати управління персоналом 3 соціальної точки зору, то можна сказати, що при цьому заходи з управління направлені на комфорт працівників. Перш за все на підприємстві приділяють увагу тому, як себе почуває працівник на роботі, чи влаштовують його умови праці, колектив та інші фрактори.

На нашу думку на якість управління персоналом майже у рівній мірі впливають усі фрактори, так як управління персоналом стосується безпосередньо персоналу, який задіяний у всіх сорерах роботи підприємства. На вітчизняних підприємствах в більшій мірі застосовують саме економічну складову управління персоналом. Для розвитку підприємств необхідно звертати увагу не лише на економічний аспект управління персоналом, а й на соціальний. Тільки тоді можна буде говорити про підвищення якості управління персоналом.

Висновки. На сучасному етапі розвитку вітчизняної і зарубіжної теорії і практики в сорері управління персоналом накопичений досить великий матеріал, вироблено інструментарій, сорормульовані основні категорії і 
Погляди вчених на сутність та значення корпоративної культури у фрункціонуванні організації

\begin{tabular}{|c|c|}
\hline Вчені & Погляд \\
\hline М. Семикіна & $\begin{array}{l}\text { Головна ідея - підвищення конкурентоспроможності вітчизняного } \\
\text { виробництва вимагає не лише зростання його технологічного рівня, } \\
\text { залучення інвестицій, але й фрормування корпоративної культури, } \\
\text { гідного стимулювання наполегливої творчої праці керівників і персоналу } \\
\text { підприємств щодо вдосконалення інноваційного менеджменту, створення } \\
\text { умов для постійного збагачення й оновлення знань, зацікавленості } \\
\text { працівників у розробці та ефеективному впровадженні нових проектів } \\
\text { і технологій. }\end{array}$ \\
\hline Г. Назарова & $\begin{array}{l}\text { Розглядає питання визначення чинників впливу рівня корпоративної } \\
\text { культури, заснованої на інноваційному управлінні та пріоритетній ролі } \\
\text { працівника у виробничому процесі. }\end{array}$ \\
\hline $\begin{array}{l}\text { К. Камерон } \\
\text { та Р. Куінн }\end{array}$ & $\begin{array}{l}\text { Пропонують оцінювати корпоративну культуру за двома вимірами: } \\
\text { перший, що характеризує ступінь гнучкості за шкалою (від організаційної } \\
\text { багатогранності до організаційної непорушності); другий вимір відрізняє } \\
\text { критерії, що підкреслюють внутрішню орієнтацію (інтеграцію та єдність), } \\
\text { від критеріїв, що асоціюються із зовнішньою орієнтацією (дифреренціацією } \\
\text { та змагальністю). Тому, фрормування корпоративної культури } \\
\text { не є одноразовим актом та передбачає процес перевірки й підвищення } \\
\text { відповідності культури цінностям, які закладені в її основу, } \\
\text { дотримання яких зумовлює довгострокове зростання ефрективності } \\
\text { та конкурентоспроможності підприємства. }\end{array}$ \\
\hline Г. Хаєт & $\begin{array}{l}\text { Визначення фенемену корпоративної культури стикається з певними } \\
\text { проблемами, перш за все методологічного характеру. Теорія корпоративної } \\
\text { культури перебуває на етапі формування та, як зазначає Г. Хаєт, } \\
\text { корпоративна культура «ще не стала стабільним усталеним зведенням } \\
\text { знань». ще не окреслено потенціал даної категорії, не досліджено } \\
\text { на } 100 \text { відсотків засоби впливу на механізм формування та розвитку } \\
\text { корпоративної культури і особливо її значення як складової конкурентних } \\
\text { переваг підприємства. }\end{array}$ \\
\hline $\begin{array}{c}\text { В. Данюк та } \\
\text { О.Чернушкіна }\end{array}$ & $\begin{array}{l}\text { Корпоративна культура - це складний культурний, духовний, психологічний, } \\
\text { соціоекономічний фенемен і її прояв здійснюється через реалізацію } \\
\text { наступних складових: ідеологія організації, цінності, культура соціально- } \\
\text { трудових відносин, правила і норми поведінки, символіка, культура } \\
\text { навчання і виховання працівників, культура праці, культура персоналу, } \\
\text { культура виробництва, культура управління, культура взаємин із зовнішнім } \\
\text { середовищем. }\end{array}$ \\
\hline
\end{tabular}

Джерело: складено авторами

підходи. У той же час проблеми, з якими стикаються і стикатимуться вітчизняні підприємства, досить складно вирішити за допомогою традиційних методів. Функціонування підприємств багато в чому визначається ефрективним взаємодією персоналу, а також результативністю системи управління персоналом.

3 точки зору ефективного управління персоналом пропонується: підвищити якість «службового життя», тобто турбота про поліпшення умов праці і побуту, щоб кожен співробітник працював на високому рівні, отримуючи задоволення від якості своєї праці; формувати здорові відносини в колективі керівник-співробітник, берегти здоров'я спів- робітників, проводити корпоративний моніторинг, бажано і застосування соціоніки, тобто оптимально використовувати персонал для виконання задумів керівника. Результати повинні поліпшити обстановку в компанії психологічну і робочу, тоді персонал буде себе почувати захищеним, за потрібне, віддача від нього збільшиться, а значить підвищиться есрективність роботи компанії.

Щодо перспектив подальших розробок можна сказати, що наразі необхідно виробити систему управління персоналом, яка буде базуватись на принципах гуманізму і розглядати працівника не як ресурс для підвищення прибутку, а насамперед як особистість. 


\section{СПИСОК ВИКОРИСТАНИХ ДЖЕРЕЛ:}

1. Мацуца А.Р. Совершенствование системы управления персоналом в торговой организации. Томск : Национальный исследовательский Томский политехнический университет, 2016. URL: http://earchive.tpu.ru/ bitstream/11683/26562/1/TPU179061.pdf

2. Уринов Б.Н. Факторы и условия, влияющие на эффективность управления персоналом. Молодой ученый. 2015. № 14(94). С. 285-287. URL: https://moluch.ru/archive/94/20702/

3. Унгурян А.С. Мотивація як складова управління персоналом та чинник конкурентних переваг» (на прикладі ПАТ «Одескабель»). Одеса : Одеський національний економічний університет, 2020. С. 10-11. URL: http://dspace.oneu.edu.ua/jspui/handle/123456789/11848

4. Никифоренко В.Г., Кравченко В.О. Корпоративна культура як складова конкурентних переваг підприємства. Вісник соціально-економічних досліджень. 2019. № 1(69). C. 189-198. URL: http://dspace.oneu.edu.ua/ jspui/handle/123456789/10023

\section{REFERENCES:}

1. Matsusa A.R. (2016) Sovershenstvovanie sistemy upravleniya personalom v torgovoi organizacii [Improvement of the personnel management system in a trade organization]. Tomsk: Natsionalniy Issledovatelsky Tomsky Politechnicheckiy Universitet. Available at: http://earchive.tpu.ru/bitstream/11683/26562/1/TPU179061.pdf (in Russian)

2. Urinov B.N. (2015) Faktory i uslovia, vliyayushie na efectivnost upravleniya personalom [Factors and conditions affecting the effectiveness of personnel management]. Molodoi ucheniy - Young scientist, 14(94), 285-287. Available at: https://moluch.ru/archive/94/20702/ (in Russian)

3. Unhurian A.S. (2020) Motivacia yak skladova upravlinnya personalom ta chinnik konkurentnih perevah (na prukladi PAT "Odeskabel") [Motivation as a component of personnel management and a factor of competitive advantage" (on the example of PJSC "Odeskabel")]. Odessa: Odesskiy Natsionalniy Economicniy Universitet. Available at: http://dspace.oneu.edu.ua/jspui/handle/123456789/11848 (in Ukrainian)

4. Nikiforenko V.G., Kravchenko V.O. (2019) Korporativna cultura yak skladova konkurentnih perevag pidpriyemstva [Corporate culture as a component of competitive advantages of the enterprise]. Visnuk socialno-economichnuh doslidgen - Bulletin of socio-economic research, 1(69), 189-198. Available at: http://dspace.oneu.edu.ua/ jspui/handle/123456789/10023 (in Ukrainian) 